\title{
UNLOCKING THE POTENTIAL OF COLLECTIONS AND ARCHAEOLOGY
}

\author{
Åsa M. Larsson \\ Swedish National Heritage Board \\ Box 5405, 11484 Stockholm, Sweden \\ asa.larsson@raa.se
}

The invitation to this special keynote discussion of Current Swedish Archaeology posed a number of questions for us to discuss or expand on. I will take the opportunity to focus on the developments I feel are necessary for archaeology and museums to take to be more than the crypt keepers of prehistory, or worse - irrelevant.

Museums and archaeology is certainly a relationship that has undergone some profound and challenging changes in Sweden over the past few decades. Partly from political changes making archaeology open to private competition, partly from the development of digital methods of documentation and dissemination. Turning information digital has afforded us opportunities that could barely be imagined by most archaeologist in the early I990s.

Theoretically we can now compare and analyse vast amounts of data in a very short time. In reality we can barely compare information from one excavation with another without substantial effort and are in fact in danger of losing much of the documentation for the future. 'Digitize the heritage' is now the rallying cry from both politicians and museums, but making something digital will not automatically make the information usable or even available. Instead, it can actually make the information less accessible. 
Digital heritage information certainly has the potential to be massively useful in ways we have only begun to realize. However, if that potential is to become reality then there are important steps that need to be taken by archaeologists and museums.

\section{THE POTENTIAL OF COLLECTIONS}

Museums are tasked with preserving collections for future generations because human experience cannot be adequately distilled into words on a page. Nor do we know everything that has happened, and these objects can help us to expand our knowledge through additional research.

It would be hubristic to say that we have retrieved as much knowledge as we possibly can from an object, as methods of research change and improve over time. At the most we may say that the cost of preserving certain objects outweighs the perceived benefits of any further knowledge to be gained from them, and that it can be replaced by documentation in some form. Most people, whether experts or laypersons, dispute neither the need for some preservation, nor the need for prioritizing what is to be added to a collection. We differ in degree rather than in kind.

Collections of course have more purposes than being research material - they are meant to be used for display and dissemination of knowledge to the public. However, most museums have collections that vastly exceed in quantity what could be exhibited in a meaningful way in a lifetime. It therefore feels as if the collections are sometimes viewed as elderly relatives that everyone agrees should be taken care of out of a sense of love and duty ('we wouldn't be here if it weren't for them, and they do make themselves useful now and then'), but who are viewed as not really pulling their weight anymore.

So can collections be made to pull their own - considerable - weight? Without a doubt, but only if we stop paying lip service to lofty ideals about collections as knowledge repositories, and start to enable them to work in that way.

We need to:

I. Unlock the full potential of collections as data.

2. Incorporate new research results into museum dissemination in a better way.

3. Have greater confidence in the public interest in history and prehistory. 
These points are interconnected. We are not working enough with developing the quality of digital data from collections and excavations, because researchers are treated as a small special-interest group, rather than as an indispensable asset for museums in public engagement and dissemination. As contract archaeology now operates as a business, archaeologists at museums are kept somewhat at a distance from the other parts of the organization. At the same time, museums with their own archaeological units are perhaps wary about opening up all their information to their potential competitors. However, this sort of thinking, where collections become a museum's private capital, will only hurt us all in the end.

Access to digital collection information cannot be restricted to privileged insiders. By restricting availability to the full content of the collection database, researchers are forced to waste time and money working as if they were still analogue. A physical object can only be housed in a single location, but digital collections are under no such limitation. Museums need to rethink the role of their collections: information need not be, should not be, restricted in this manner. Researchers are doing the essential work to generate new knowledge that ensures that both collections and new excavations are valued by society.

Museums should never ask Why something should be made available online, but rather ask Why not? If the objection is a sense of ownership then the museum is not living up to its fundamental duty towards the public in any meaningful way. More commonly the objection is lack of know-how and resources (budget as well as staff), and we have to work together to find ways to overcome that. Making collections available and usable is surely the best way to ensure that they as well as the curators will continue to receive funding. We are dangerously naïve if we think the people holding the purse strings are not prepared to pull the plug on 'useless' collections taking up space and resources. After all, if the purpose of a museum is only its exhibits, why even have a collection of stuff that will never be shown? If everything that can be learnt about an excavated site is presented in the report, then why keep anything afterwards?

\section{ARCHAEOLOGISTS NEED TO STEP UP}

I have spent a lot of time exhorting museums to rethink their collections so that they make better use of the digital potentials. However, I will not let archaeologists off the hook. What responsibility do we take, as members of a profession, to live up to the goals of documenting an excavation in a manner that is usable for others to critically examine and 
re-interpret? What responsibility do we take to work together to make sure we are using common semantics when possible, so that data can be compared and analysed?

It is remarkable how poor we have been at making sure we use the same terminology in even very basic documentation, which could ensure computer-based analyses and statistics without extensive re-digitization. We are focusing so much effort on using digital tools during excavations that we rarely stop to ask how to make sure product will be usable in another context. We still mostly think in an analogue manner, leaving vital information out which would ensure that data can be related to each other.

Yes, there should be better infrastructures in place to make sure archiving and dissemination of digital information is ensured, and some of it is in progress at Riksantikvarieämbetet (the National Heritage Board). But I strongly believe professionals need to take an active part in making sure archaeology develops standards that do the most good, and the least harm. Museum archaeologists should be in a better position than most others to work with these issues, both because they can collaborate across many museums ensuring multiple viewpoints, and because they can collaborate with the collection curators.

\section{RETHINK DISSEMINATION}

Finally, we must rethink what we mean by dissemination, finding ways to share knowledge. We must make sure that the information we collect in the field, the information we store at museums, and the information being created through research, are not wholly different products with little or no connection between them.

Yes, the situation has become quite challenging: archaeologists being in competition with each other, the growing wedge between field archaeologists and university researchers, and the financial difficulties of many museums. These are reasons for our current problems, but they are not excuses. We can and should create forums for dealing with common issues, and we can do a lot more to make sure we are actually delivering on our promises.

Archaeologists must learn how to create digital information in a manner that better ensures its re-usability. Museums need to make it easier for everyone to engage with their collections in order to unlock their massive potential. We all need to make a much better effort to make sure information is preserved and made available, so that future excavations are made from a position of improved knowledge. 
We need to put more effort into developing best practices and methods ensuring that heritage data can be used to create new knowledge and insight into the past, and through this a better understanding of our present.

I will end with some hopeful suggestions for archaeology and museums:

- Collaborate to develop 'best practices' for documenting digital information.

- Make use of good principles when creating and sharing data: i.e. persistent identifiers and Linked Open Data.

- Make digital collection data at museums open and free to use. 